\title{
Microwave Dielectric Properties of Sr-Substituted $\mathrm{Ba}\left(\mathrm{Mg}_{0.5} \mathrm{~W}_{0.5}\right) \mathrm{O}_{3}$ Ceramics
}

\author{
Sang-Ok Yoon, Dong-Kyu Choi, Jun-Hyuk Oh, and Shin Kim ${ }^{\dagger}$ \\ Department of Advanced Ceramic Materials Engineering, Gangneung-Wonju National University, Gangneung 25457, Korea \\ (Received April 13, 2018; Revised May 18, 2018; Accepted May 18, 2018)
}

\begin{abstract}
The phase evolution, microstructure, and microwave dielectric properties of Sr-substituted $\mathrm{Ba}\left(\mathrm{Mg}_{0.5} \mathrm{~W}_{0.5}\right) \mathrm{O}_{3}$ ceramics, i.e., $\left(\mathrm{Ba}_{1-\mathrm{x}} \mathrm{Sr}_{\mathrm{x}}\right)\left(\mathrm{Mg}_{0.5} \mathrm{~W}_{0.5}\right) \mathrm{O}_{3}(0 \leq \mathrm{x} \leq 0.30)$, sintered at $1700^{\circ} \mathrm{C}$ for $1 \mathrm{~h}$ were investigated. All compositions showed a $1: 1$ ordered perovskite structure. In all the compositions, $\mathrm{BaWO}_{4}$ was detected as the secondary phase. With increasing $\mathrm{x}$ in $\left(\mathrm{Ba}_{1-\mathrm{x}} \mathrm{Sr}_{\mathrm{x}}\right)$ $\left(\mathrm{Mg}_{0.5} \mathrm{~W}_{0.5}\right) \mathrm{O}_{3}$, the lattice parameter increased linearly, indicating that a substitutional solid solution occurred. All compositions exhibited a dense microstructure. The value of $\varepsilon_{\mathrm{r}}$ increased slightly with increasing $\mathrm{x}$. The value of $\mathrm{Q} \times \mathrm{f}_{0}$ increased with the increase in $\mathrm{x}$ up to $\mathrm{x}=0.10$ and reached a saturated value of about 100,000 GHz. The composition for $\mathrm{x}=0.20$, i.e., $\left(\mathrm{Ba}_{0.80} \mathrm{Sr}_{0.20}\right)\left(\mathrm{Mg}_{0.5} \mathrm{~W}_{0.5}\right) \mathrm{O}_{3}$, sintered at $1700^{\circ} \mathrm{C}$ for $1 \mathrm{~h}$ exhibited superior microwave dielectric properties of $\varepsilon_{\mathrm{r}}=19.6, \mathrm{Q} \times \mathrm{f}_{0}=99,358$ $\mathrm{GHz}$, and $\tau_{\mathrm{f}}=0.0 \mathrm{ppm} /{ }^{\circ} \mathrm{C}$, respectively.
\end{abstract}

Key words : $\mathrm{Ba}\left(\mathrm{Mg}_{0.5} \mathrm{~W}_{0.5}\right) \mathrm{O}_{3}$, Ordered perovskite, Dielectric constant, Quality factor, Temperature coefficient of resonant frequency

\section{Introduction}

M otivated by the rapid growth of the commercial wireless communication industry, research on microwave dielectric ceramics used for mobile phones, wireless local area networks (LAN), global positioning system (GPS), and intelligent transport systems (ITS) is being actively con-

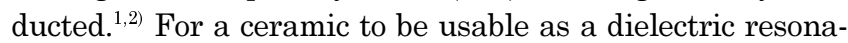
tor/filter, three key properties need to be optimized; dielectric constant, $\varepsilon_{\mathrm{r}}$, should fulfill the condition $20<\varepsilon_{\mathrm{r}}<50$, dielectric loss or its inverse, the quality factor, $\mathrm{Q}>30,000$ at 1 $\mathrm{GHz}$, and the temperature coefficient of resonant frequency, $\tau_{\mathrm{f}} \sim \pm 3 \mathrm{ppm} /{ }^{\circ} \mathrm{C}$. ${ }^{3)}$ Structural stability and microwave dielectric properties of $\mathrm{Ba}\left(\mathrm{Mg}_{0.5} \mathrm{~W}_{0.5}\right) \mathrm{O}_{3}$ systems with a $1: 1$ ordered perovskite structure have been investigated wide$\mathrm{ly}^{4-14)}$ ever since Takahashi et al. reported the dielectric properties of $\mathrm{Ba}\left(\mathrm{Mg}_{0.5} \mathrm{~W}_{0.5}\right) \mathrm{O}_{3}$ ceramics with $\varepsilon_{\mathrm{r}}=16.7, \mathrm{Q} \times \mathrm{f}_{0}$ $=42,000 \mathrm{GHz}$, and $\tau_{\mathrm{f}}=-33.6 \mathrm{ppm} /{ }^{\circ} \mathrm{C}$. ${ }^{4)} \mathrm{Wu}$ et al. reported that for $\mathrm{x}=0.02$, the $(1-\mathrm{x}) \mathrm{Ba}\left(\mathrm{Mg}_{0.5} \mathrm{~W}_{0.5}\right) \mathrm{O}_{3}-(\mathrm{x}) \mathrm{Ba}\left(\mathrm{Y}_{0.67} \mathrm{~W}_{0.33}\right) \mathrm{O}_{3}$ system exhibited dielectric behavior with $\varepsilon_{\mathrm{r}}=20, \mathrm{Q} \times \mathrm{f}_{0}=$ $160,000 \mathrm{GHz}$, and $\tau_{\mathrm{f}}=-21 \mathrm{ppm} /{ }^{\circ} \mathrm{C} .{ }^{10)}$ Bian and $\mathrm{Wu}$ reported that for $\mathrm{x}=0.30$, the $\mathrm{Ba}\left[\left\{\mathrm{Mg}_{(1-\mathrm{x}) / 2} \mathrm{Y}_{\mathrm{x} / 3}\left(\square_{\mathrm{Mg}}\right)_{\mathrm{x} / 6}\right\} \mathrm{W}_{1 / 2}\right] \mathrm{O}_{3}$ ( $\square$ refers to the vacancy) system exhibited dielectric behavior with $\varepsilon_{\mathrm{r}}$ $=21.9, \mathrm{Q} \times \mathrm{f}_{0}=133,000 \mathrm{GHz}$, and $\tau_{\mathrm{f}}=-2.4 \mathrm{ppm} /{ }^{\circ} \mathrm{C}{ }^{13)} \mathrm{Lin}$ et al. investigated the microwave dielectric properties of the $\left(\mathrm{Ba}_{1-\mathrm{x}} \mathrm{Sr}_{\mathrm{x}}\right)\left(\mathrm{Mg}_{0.5} \mathrm{~W}_{0.5}\right) \mathrm{O}_{3}$ system with the compositions at wide intervals of $\mathrm{x}=0,0.25,0.50$, and 0.75 and found that at $\mathrm{x}=$

${ }^{\dagger}$ Corresponding author: Shin Kim

E-mail : perovskite@gwnu.ac.kr

Tel : +82-33-640-2360 Fax : +82-33-640-2244
0.25 , the system exhibited the following dielectric properties: $\varepsilon_{\mathrm{r}}=20.6, \mathrm{Q} \times \mathrm{f}_{0}=152,600 \mathrm{GHz}$, and $\tau_{\mathrm{f}}=+24 \mathrm{ppm} /{ }^{\circ} \mathrm{C} .{ }^{12)}$ In this study, we have investigated the phase evolution, microstructure, and microwave dielectric properties of the $\left(\mathrm{Ba}_{1-\mathrm{x}} \mathrm{Sr}_{\mathrm{x}}\right)\left(\mathrm{Mg}_{0.5} \mathrm{~W}_{0.5}\right) \mathrm{O}_{3}$ system with $0 \leq \mathrm{x} \leq 0.30$ at intervals of $0.05 \mathrm{~mol}$.

\section{Experimental Procedure}

Raw powders of $\mathrm{BaCO}_{3}$ (purity 2N5, Sakai Chem. Ind. Co., Ltd., Japan), $\mathrm{SrCO}_{3}$ (3N, High Purity Chem. Co., Ltd., Japan), $\mathrm{MgO}$ (2N, High Purity Chem. Co., Ltd., Japan), and $\mathrm{WO}_{3}$ (3N, High Purity Chem. Co., Ltd., Japan) were mixed to prepare the $\left(\mathrm{Ba}_{1-\mathrm{x}} \mathrm{Sr}_{\mathrm{x}}\right)\left(\mathrm{Mg}_{0.5} \mathrm{~W}_{0.5}\right) \mathrm{O}_{3}$ ceramics. Appropriate ratios of the raw powders were ball-milled using zirconia balls and ethyl alcohol in a polyethylene container for $24 \mathrm{~h}$. After drying in an oven, the powder mixture was calcined at $900^{\circ} \mathrm{C}$ for $10 \mathrm{~h}$ in an alumina crucible, followed by pulverizing and uniaxial pressing at $50 \mathrm{MPa}$ to form disk-type specimen $15 \mathrm{~mm}$ in diameter. The disk-type specimens were sintered at $1700^{\circ} \mathrm{C}$ for $1 \mathrm{~h}$. The crystalline phases of the sintered specimens were identified using a powder X-ray diffractometer (XRD, D/MAX-2500V/PC, Rigaku, Japan). The apparent lattice parameter, $a$, of the cubic structure was calculated using the equation of $a^{2}=\left[\left(h^{2}+k^{2}+l^{2}\right) \lambda^{2}\right] /$ $\left(4 \sin ^{2} \theta\right)$, where $\theta$ is the angle of diffraction of the X-rays from the plane of $(h k l)$ and $l$ is the wave length of the Xrays. The lattice parameter was determined by plotting the calculated $a$ values versus the Nelson-Riley function $f(\theta)$ $\left(f(\theta)=1 / 2\left(\cos ^{2} \theta / \sin \theta+\cos ^{2} \theta / \theta\right)\right)$ and determining the $\mathrm{y}-$ intercept where the Nelson-Riley function went to zero, i.e., 
at $\theta=\pi / 2$. Microstructure of the sintered specimens was characterized by a field emission scanning electron microscope (FE-SEM, Quanta 250 FEG, FEI, U.S.A.). The microwave dielectric properties of the specimens were determined using network analyzers. The dielectric constant was measured by Hakki-Coleman method using a network analyzer (E5071C, Keysight, U.S.A.). The quality factors of the sintered specimens were measured by the cavity method using the same equipment. The temperature coefficient of resonant frequency was measured by the cavity method using a network analyzer (R3767CG, Advantest, Japan) in the temperature range of $20^{\circ} \mathrm{C}$ to $80^{\circ} \mathrm{C}$.

\section{Results and Discussion}

The powder X-ray diffraction patterns of $\left(\mathrm{Ba}_{1-\mathrm{x}} \mathrm{Sr}_{\mathrm{x}}\right)$ $\left(\mathrm{Mg}_{0.5} \mathrm{~W}_{0.5}\right) \mathrm{O}_{3}(\mathrm{x}=0,0.05,0.10,0.15,0.20,0.25$, and 0.30) ceramics sintered at $1700^{\circ} \mathrm{C}$ are shown in Fig. 1. All compositions show a $1: 1$ ordered perovskite structure, i.e., an ordered arrangement of $\mathrm{MgO}_{6}$ and $\mathrm{WO}_{6}$ octahedra in B-site of the perovskite structure. In all the compositions, $\mathrm{BaWO}_{4}$ is detected as the secondary phase. It was reported that $\mathrm{BaWO}_{4}$ is usually formed during the sintering of $\mathrm{Ba}\left(\mathrm{Mg}_{0.5} \mathrm{~W}_{0.5}\right) \mathrm{O}_{3}$ due to its structural instability at high temperatures. ${ }^{5,8-10)}$ Khalyavin et al. suggested a mass balance reaction of $\mathrm{Ba}_{2} \mathrm{MgWO}_{6} \rightarrow \mathrm{BaWO}_{4}+\mathrm{MgO}+\mathrm{BaO}$ as a possible mechanism for the formation of $\mathrm{BaWO}_{4}{ }^{5)}$ The peak at $2 \theta$ $\sim 42.9^{\circ}$ may correspond to the (200) plane of MgO (ICDD number 45-0946) and/or the (204) plane of $\mathrm{BaWO}_{4}$ (ICDD number 43-0646). There was no inter-dependency between the amount of $\mathrm{BaWO}_{4}$ calculated from the intensity ratio of $\mathrm{I}_{(110) \quad B a W 0} / \mathrm{I}_{(220)} \mathrm{Ba}\left(\mathrm{Mg} 0.5 \mathrm{WW0.5)O3}\right.$ and value of $\mathrm{x}$ in $\left(\mathrm{Ba}_{1-\mathrm{x}} \mathrm{Sr}_{\mathrm{x}}\right)_{-}$ $\left(\mathrm{Mg}_{0.5} \mathrm{~W}_{0.5}\right) \mathrm{O}_{3}$. The minimum value of the intensity ratio $\mathrm{I}_{(110)}$ ${ }_{\mathrm{BaWO} 4} / \mathrm{I}_{(220) \mathrm{Ba}(\mathrm{Mg0.5W0.5)O3}}$ is obtained for the composition with $\mathrm{x}$ $=0.10$. The presence of $\mathrm{MgO}$ or Mg-rich phases in the sintered specimens of $\mathrm{Ba}\left(\mathrm{Mg}_{0.5} \mathrm{~W}_{0.5}\right) \mathrm{O}_{3}$ ceramics has been previously reported. ${ }^{5,8)}$ Similar to other studies, $\mathrm{BaO}$ is not detected in any of the compositions in this study. It was pre-

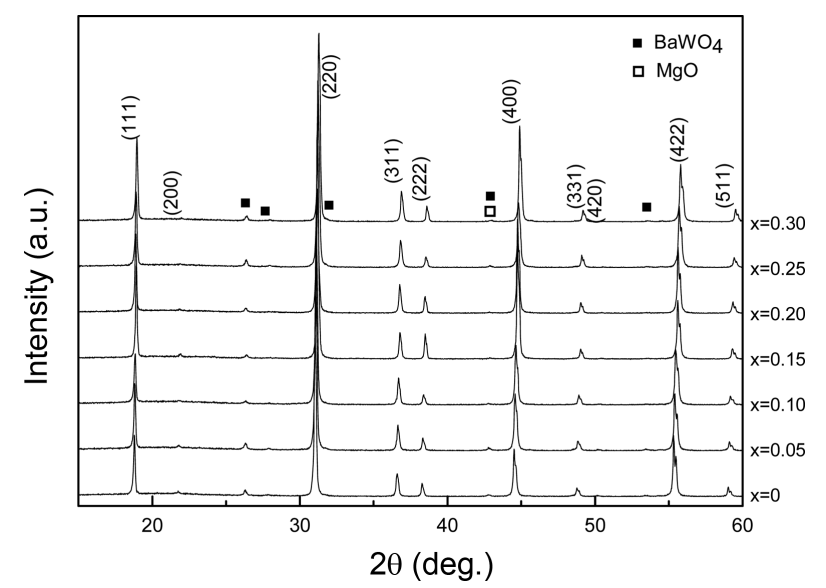

Fig. 1. Powder X-ray diffraction patterns of the $\left(\mathrm{Ba}_{1-\mathrm{x}} \mathrm{Sr}_{\mathrm{x}}\right)$ $\left(\mathrm{Mg}_{0.5} \mathrm{~W}_{0.5}\right) \mathrm{O}_{3}$ ceramics.

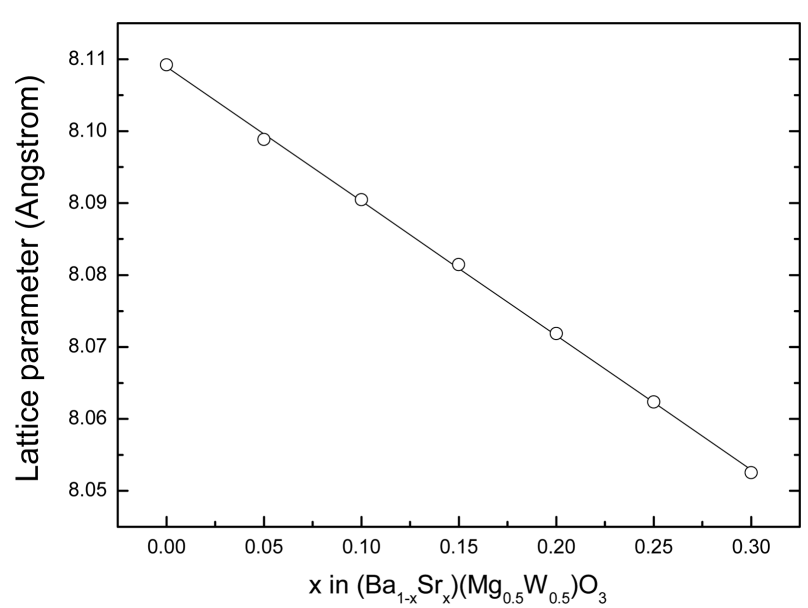

Fig. 2. Lattice parameter of the $\left(\mathrm{Ba}_{1-\mathrm{x}} \mathrm{Sr}_{\mathrm{x}}\right)\left(\mathrm{Mg}_{0.5} \mathrm{~W}_{0.5}\right) \mathrm{O}_{3}$ ceramics as a function of $\mathrm{x}$.

viously suggested that $\mathrm{BaO}$ might exist in the amorphous state or as a solid solution with $\mathrm{Ba}\left(\mathrm{Mg}_{0.5} \mathrm{~W}_{0.5}\right) \mathrm{O}_{3}$ or $\mathrm{BaWO}_{4}{ }^{6,8)}$

The lattice parameters of $\left(\mathrm{Ba}_{1-\mathrm{x}} \mathrm{Sr}_{\mathrm{x}}\right)\left(\mathrm{Mg}_{0.5} \mathrm{~W}_{0.5}\right) \mathrm{O}_{3}$ ceramics are shown in Fig. 2. With increasing $\mathrm{x}$ in $\left(\mathrm{Ba}_{1-\mathrm{x}} \mathrm{Sr}_{\mathrm{x}}\right)\left(\mathrm{Mg}_{0.5} \mathrm{~W}_{0.5}\right) \mathrm{O}_{3}$, the lattice parameter decreases linearly indicating that a substitutional solid solution occurs. The substitution of $\mathrm{Ba}^{2+}$ ion by a smaller $\mathrm{Sr}^{2+}$ ion, where the ionic radii of $\mathrm{Sr}^{2+}$ ion and $\mathrm{Ba}^{2+}$ ion are $1.44 \AA$ and $1.61 \AA$, respectively, when the coordination number is 12 , may be the cause for the decrease in the value of lattice parameter. ${ }^{15)}$ The lattice parameter of $\mathrm{Ba}\left(\mathrm{Mg}_{0.5} \mathrm{~W}_{0.5}\right) \mathrm{O}_{3}$ sintered at $1700^{\circ} \mathrm{C}$ in this study is 8.1092(3) $\AA$ and it was reported as between 8.1072 $\AA$ (sintered at $1650^{\circ} \mathrm{C}$ ) and $8.1115 \AA$ (sintered at $\left.1600^{\circ} \mathrm{C}\right)$. $^{5)}$ The typical FE-SEM images of $\left(\mathrm{Ba}_{1-\mathrm{x}} \mathrm{Sr}_{\mathrm{x}}\right)\left(\mathrm{Mg}_{0.5} \mathrm{~W}_{0.5}\right) \mathrm{O}_{3}$ ceramics (the compositions with $\mathrm{x}=0,0.10$, and 0.30 ) are shown in Fig. 3. All the compositions exhibit a dense microstructure and the grain shape is certainly a polyhedron.

The linear shrinkage, the dielectric constant $\left(\varepsilon_{\mathrm{r}}\right)$, and the quality factor $\left(\mathrm{Q} \times \mathrm{f}_{0}\right)$ are illustrated in Fig. 4. The linear shrinkage of the composition for $\mathrm{x}=0$, i.e., $\mathrm{Ba}\left(\mathrm{Mg}_{0.5} \mathrm{~W}_{0.5}\right) \mathrm{O}_{3}$, is much lower than that of other compositions. The linear shrinkage increases with the increase of $\mathrm{x}$ except for the composition with $\mathrm{x}=0.25$, implying that the sinterability of $\mathrm{Ba}\left(\mathrm{Mg}_{0.5} \mathrm{~W}_{0.5}\right) \mathrm{O}_{3}$ ceramics is improved by the Sr substitution. In addition, it is considered that its sinterability is improved by the liquid phase sintering due to the formation of $\mathrm{BaWO}_{4}$ having a low melting point of $1430^{\circ} \mathrm{C} .^{12)}$

The variation of $\varepsilon_{\mathrm{r}}$ is similar to that of the linear shrinkage. The value of $\varepsilon_{\mathrm{r}}$ for the composition with $\mathrm{x}=0$ is 17.3 and it was reported as 16.7 (sintered at $1500^{\circ} \mathrm{C}$. $^{4)}$ ), 17.6 (sintered at $\left.1600^{\circ} \mathrm{C}^{5}\right)$, and 18.9 (sintered at $1575^{\circ} \mathrm{C}^{12)}$ ) earlier. The value of $\varepsilon_{\mathrm{r}}$ increases slightly with increasing $\mathrm{x}$ except for the composition with $\mathrm{x}=0.10$. It is considered that the relatively high $\varepsilon_{\mathrm{r}}$ of the composition with $\mathrm{x}=0.10$ may be due to the presence of small amount of $\mathrm{BaWO}_{4}$ having a low $\varepsilon_{\mathrm{r}}$ of $8.1^{16)}$ as mention above. The value of $\mathrm{Q} \times \mathrm{f}_{0}$ for $\mathrm{Ba}\left(\mathrm{Mg}_{0.5} \mathrm{~W}_{0.5}\right) \mathrm{O}_{3}$ ceramics is $59,738 \mathrm{GHz}$, which is higher than that reported by Takahashi et al. ${ }^{4)}$ and lower than that 

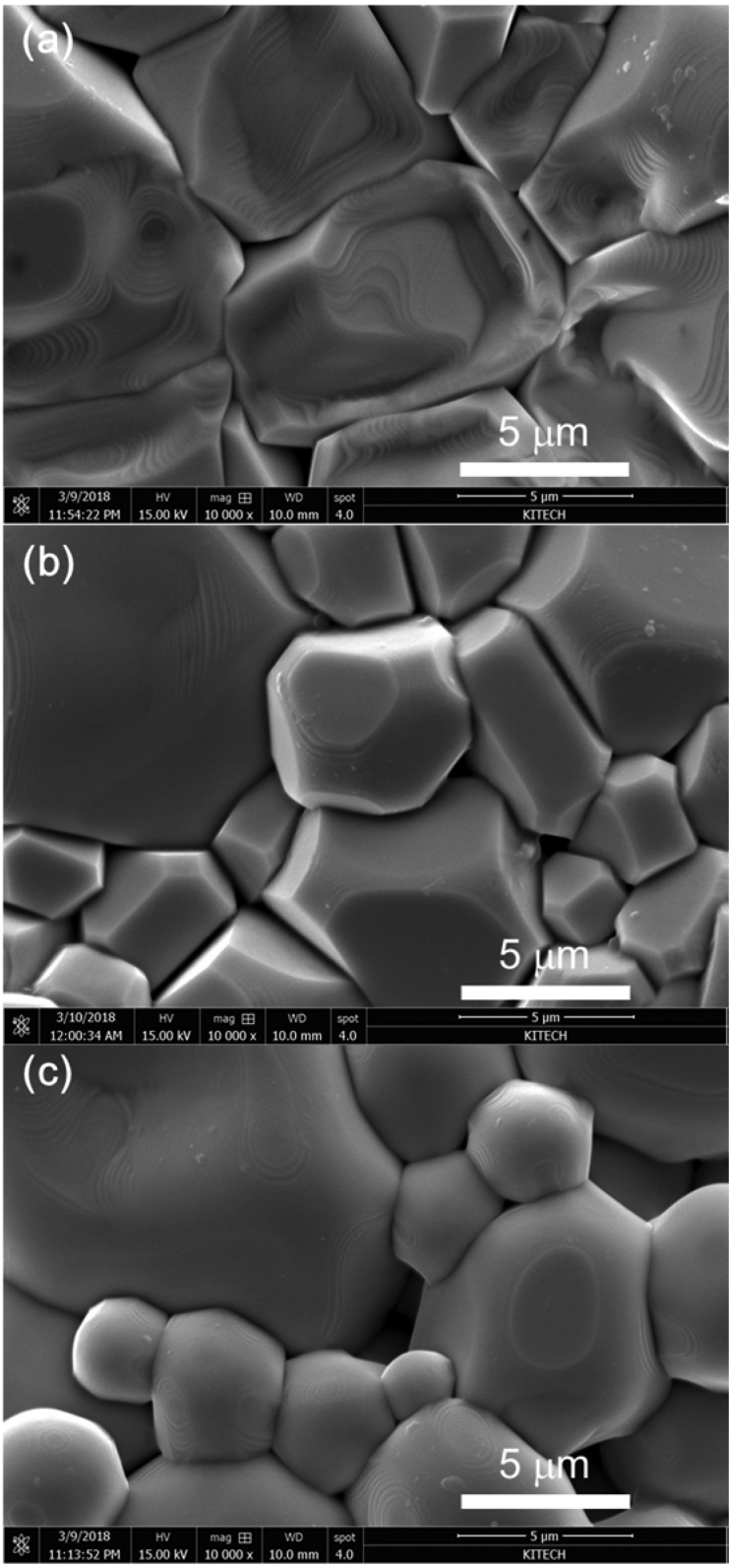

Fig. 3. FE-SEM images of the $\left(\mathrm{Ba}_{1-\mathrm{x}} \mathrm{Sr}_{\mathrm{x}}\right)\left(\mathrm{Mg}_{0.5} \mathrm{~W}_{0.5}\right) \mathrm{O}_{3}$ ceramics; (a) $\mathrm{x}=0$, (b) $\mathrm{x}=0.10$, and (c) $\mathrm{x}=0.30$

reported by Lin et al... ${ }^{2)}$ The value of $\mathrm{Q} \times \mathrm{f}_{0}$ increases with increase in $\mathrm{x}$ up to $\mathrm{x}=0.10$ and reaches a saturated value of about $100,000 \mathrm{GHz}$. It is considered that the increase in $\mathrm{Q} \times$ $\mathrm{f}_{0}$ may be related to the improvement in sinterability owing to the substitution of $\mathrm{Ba}^{2+}$ ion by $\mathrm{Sr}^{2+}$ ion and the liquid phase sintering as mentioned above. The dielectric losses or the inverse of the quality factor are generally classified into intrinsic and extrinsic categories. The intrinsic dielectric losses depend on the crystal structure, ac field frequency and temperature. The extrinsic losses are associated with the microstructure, e.g., pores, grain boundaries, and secondary phases. ${ }^{9)}$ Reany and Iddles have pointed out that, in reality, extrinsic losses dominate the quality factor. ${ }^{3)}$

The temperature coefficient of resonant frequency $\left(\tau_{f}\right)$ as a

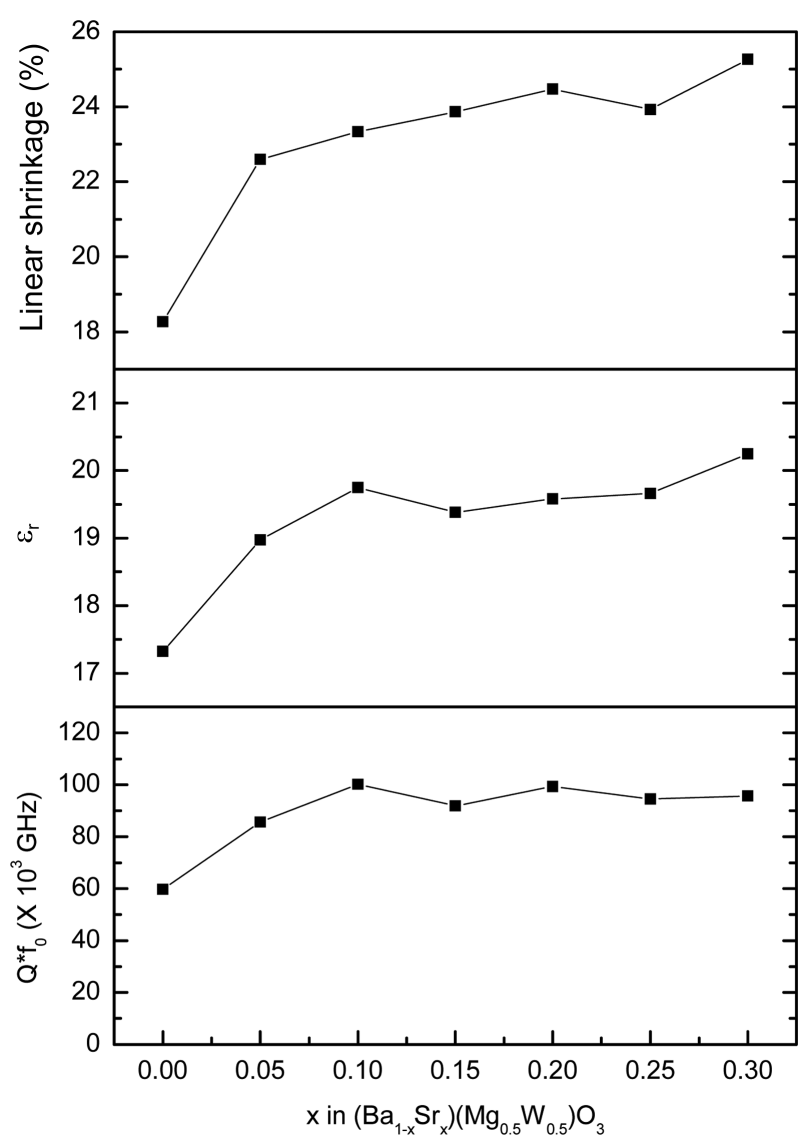

Fig. 4. Linear shrinkage, dielectric constant $\left(\varepsilon_{\mathrm{r}}\right)$, and quality factor $\left(\mathrm{Q} \times \mathrm{f}_{0}\right)$ of the $\left(\mathrm{Ba}_{1-\mathrm{x}} \mathrm{Sr}_{\mathrm{x}}\right)\left(\mathrm{Mg}_{0.5} \mathrm{~W}_{0.5}\right) \mathrm{O}_{3}$ ceramics as a function of $\mathrm{x}$.

function of the calculated tolerance factor (t) using Shannon ionic radii is illustrated in Fig. 5. ${ }^{15)}$ The value of $\tau_{\mathrm{f}}$ for the $\left(\mathrm{Ba}_{1-\mathrm{x}} \mathrm{Sr}_{\mathrm{x}}\right)\left(\mathrm{Mg}_{0.5} \mathrm{~W}_{0.5}\right) \mathrm{O}_{3}$ ceramics increases from a negative value to a positive one with increasing $\mathrm{x}$. It was reported that $\tau_{\mathrm{f}}$ is related to the temperature coefficient of the dielec-

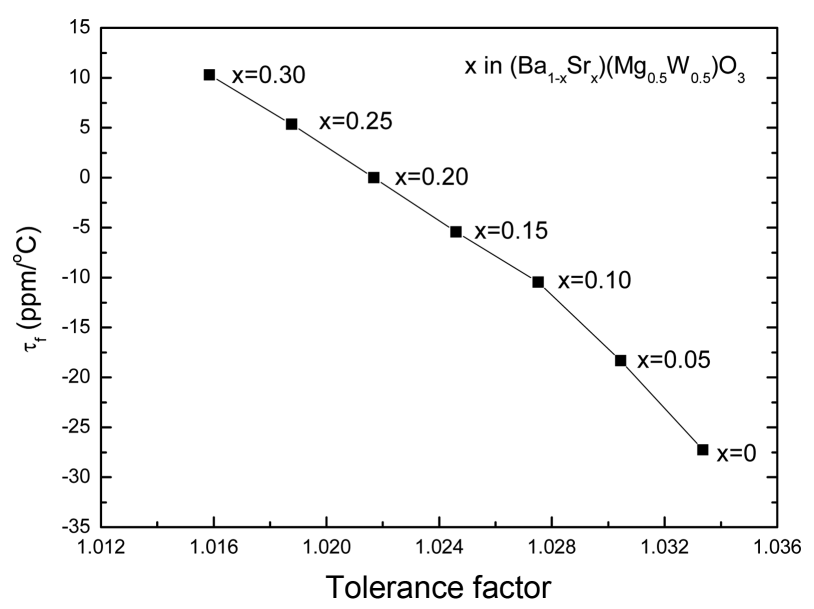

Fig. 5. Temperature coefficient of resonant frequency $\left(\tau_{\mathrm{f}}\right)$ of the $\left(\mathrm{Ba}_{1 . \mathrm{x}} \mathrm{Sr}_{\mathrm{x}}\right)\left(\mathrm{Mg}_{0.5} \mathrm{~W}_{0.5}\right) \mathrm{O}_{3}$ ceramic as a function of tolerance factor. 
tric constant $\left(\tau_{\varepsilon}\right)$ and the linear thermal expansion coefficient $\left(\alpha_{\mathrm{L}}\right)$ by $\tau_{\mathrm{f}}=-\left(\tau_{\varepsilon} / 2+\alpha_{\mathrm{L}}\right){ }^{3)}$ In addition an overall empirical correlation between $\tau_{\varepsilon}$ and the tolerance factor of the perovskite structure $(\mathrm{t})$ is given by $\mathrm{t}=\left(R_{A}+R_{O}\right) /\left[\sqrt{2}\left(R_{B}\right.\right.$ $\left.+R_{O}\right)$ ] where $R_{A}, R_{B}$, and $R_{O}$ are the ionic radii of $\mathrm{A}, \mathrm{B}$, and oxygen ions in the $\mathrm{ABO}_{3}$ perovskite structure, has been established by Reaney et al.. ${ }^{17)}$ The value of $\tau_{\mathrm{f}}$ in this study ranges from $-27.3 \mathrm{ppm} /{ }^{\circ} \mathrm{C}$ for the composition with $\mathrm{x}=0$, which is similar to that reported by Lin et al. ${ }^{12)}$ to $10.3 \mathrm{ppm} /$ ${ }^{\circ} \mathrm{C}$ for the composition with $\mathrm{x}=0.30$ and zero value of $\tau_{\mathrm{f}}$ is obtained for the composition with $\mathrm{x}=0.20$. The composition with $\mathrm{x}=0.20$, i.e., $\left(\mathrm{Ba}_{0.80} \mathrm{Sr}_{0.20}\right)\left(\mathrm{Mg}_{0.5} \mathrm{~W}_{0.5}\right) \mathrm{O}_{3}$, sintered at $1700^{\circ} \mathrm{C}$ for $1 \mathrm{~h}$, exhibits superior microwave dielectric properties of $\varepsilon_{\mathrm{r}}=19.6, \mathrm{Q} \times \mathrm{f}_{0}=99,358 \mathrm{GHz}$, and $\tau_{\mathrm{f}}=0.0 \mathrm{ppm} /{ }^{\circ} \mathrm{C}$.

\section{Conclusions}

The phase evolution, microstructure, and microwave dielectric properties of $\mathrm{Sr}$-substituted $\mathrm{Ba}\left(\mathrm{Mg}_{0.5} \mathrm{~W}_{0.5}\right) \mathrm{O}_{3}$ ceramics, i.e., $\left(\mathrm{Ba}_{1-\mathrm{x}} \mathrm{Sr}_{\mathrm{x}}\right)\left(\mathrm{Mg}_{0.5} \mathrm{~W}_{0.5}\right) \mathrm{O}_{3}(0 \leq \mathrm{x} \leq 0.30)$, sintered at $1700^{\circ} \mathrm{C}$ for $1 \mathrm{~h}$ were investigated. All compositions showed a $1: 1$ ordered perovskite structure. In all the compositions, $\mathrm{BaWO}_{4}$ was detected as the secondary phase. With increasing $\mathrm{x}$ in $\left(\mathrm{Ba}_{1-\mathrm{x}} \mathrm{Sr}_{\mathrm{x}}\right)\left(\mathrm{Mg}_{0.5} \mathrm{~W}_{0.5}\right) \mathrm{O}_{3}$, the lattice parameter increased linearly, indicating that a substitutional solid solution occurred. All compositions exhibited a dense microstructure and the grain shape was confirmed to be a polyhedron. The linear shrinkage increased with the increase in $x$ except for the composition with $\mathrm{x}=0.25$, implying that the sinterability of $\mathrm{Ba}\left(\mathrm{Mg}_{0.5} \mathrm{~W}_{0.5}\right) \mathrm{O}_{3}$ ceramics was improved by the substitution of $\mathrm{Sr}$. The value of $\varepsilon_{\mathrm{r}}$ increased slightly with increasing $\mathrm{x}$ except for the composition with $\mathrm{x}=0.10$. The value of $\mathrm{Q} \times \mathrm{f}_{0}$ increased with increase in $\mathrm{x}$ up to $\mathrm{x}=0.10$ and reached a saturated value about $100,000 \mathrm{GHz}$. The composition with $\mathrm{x}=0.20$, i.e., $\left(\mathrm{Ba}_{0.80} \mathrm{Sr}_{0.20}\right)\left(\mathrm{Mg}_{0.5} \mathrm{~W}_{0.5}\right) \mathrm{O}_{3}$, sintered at $1700^{\circ} \mathrm{C}$ for $1 \mathrm{~h}$ exhibited superior microwave dielectric properties with $\varepsilon_{\mathrm{r}}=19.6, \mathrm{Q} \times \mathrm{f}_{0}=99,358 \mathrm{GHz}$, and $\tau_{\mathrm{f}}=$ $0.0 \mathrm{ppm} /{ }^{\circ} \mathrm{C}$, respectively.

\section{Acknowledgments}

This study was supported by Gangneung-Wonju National University.

\section{REFERENCES}

1. H. Ohsato, T. Tsunooka, M. Ando, Y. Ohishi, Y. Miyauchi, and K. Kakimoto, "Millimeter-Wave Dielectric Ceramics of Alumina and Forsterite with High Quality Factor and Low Dielectric Constant," J. Korean Ceram. Soc., 40 [4] 350-53 (2003).

2. H. Ohsato, M. Ando, and T. Tsunooka, "Synthesis of Forsterite with High Q and Near Zero $\mathrm{TC}_{\mathrm{f}}$ for Microwave/Millimeterwave Dielectrics," J. Korean Ceram. Soc., 44 [11] 597-606 (2007).
3. I. M. Reaney and D. Iddles, "Microwave Dielectric Ceramics for Resonators and Filters in Mobile Phone Networks," J. Am. Ceram. Soc., 89 [7] 2063-72 (2006).

4. H. Takahashi, K. Ayusawa, and N. Sakamoto, "Microwave Dielectric Properties of $\mathrm{Ba}\left(\mathrm{Mg}_{1 / 2} \mathrm{~W}_{1 / 2}\right) \mathrm{O}_{3}-\mathrm{BaTiO}_{3}$ Ceramics," Jpn. J. Appl. Phys., 36 [9A] 5597-99 (1997).

5. D. D. Khalyavin, J. Han, A. M. R. Senos, and P. Q. Mantas, "Synthesis and Dielectric Properties of TungstenBased Complex Perovskites," J. Mater. Res., 18 [11] 26007 (2003).

6. J. J. Bian, K. Yan, and Y. F. Dong, "Microwave Dielectric Properties of $\mathrm{A}_{1-3 \mathrm{x} / 2} \mathrm{La}_{\mathrm{x}}\left(\mathrm{Mg}_{1 / 2} \mathrm{~W}_{1 / 2}\right) \mathrm{O}_{3}(\mathrm{~A}=\mathrm{Ba}, \mathrm{Sr}, \mathrm{Ca} ; 0.0 \leq \mathrm{x}$ $\leq$ 0.05) Double Perovskites," Mater. Sci. Eng. B, 147 [1] 27-34 (2008).

7. J. J. Bian, Y. F. Dong, and G. X. Song, "Structural Evolution and Microwave Dielectric Properties of (1-x)BaZn $\mathrm{Br}_{1 / 3} \mathrm{Nb}_{2 / 3}$ $\mathrm{O}_{3+\mathrm{x}} \mathrm{BaMg}_{1 / 2} \mathrm{~W}_{1 / 2} \mathrm{O}_{3}$ Ceramics," J. Electroceram., 22 [4] 39094 (2009).

8. J. Y. Wu and J. J. Bian, "Structure Stability and Microwave Dielectric Properties of Double Perovskite Ceramics - $\mathrm{Ba}_{2} \mathrm{Mg}_{1-\mathrm{x}} \mathrm{Ca}_{\mathrm{x}} \mathrm{WO}_{6}(0.0 \leq \mathrm{x} \leq 0.15)$," Ceram. Int., 38 [4] 3217-25 (2012).

9. J. Y. Wu and J. J. Bian, "Effect of Nonstoichiometry on the Microstructure and Microwave Dielectric Properties of $\mathrm{Ba}\left(\mathrm{Mg}_{1 / 2} \mathrm{~W}_{1 / 2}\right) \mathrm{O}_{3}$ Ceramics," Ceram. Int., 39 [4] 3641-49 (2013).

10. J. Y. Wu and J. J. Bian, "Structure Stability and Microwave Dielectric Properties of (1-x)Ba( $\left(\mathrm{Mg}_{1 / 2} \mathrm{~W}_{1 / 2}\right) \mathrm{O}_{3}+$ $\mathrm{xBa}\left(\mathrm{Y}_{2 / 3} \mathrm{~W}_{1 / 3}\right) \mathrm{O}_{3}$ Ceramics," J. Am. Ceram. Soc., 97 [3] 88084 (2014).

11. J. Bian, J. Wu, R. Ubic, C. Karthik, and Y. Wu, "Structural Stability and Microwave Dielectric Properties of $(1-\mathrm{x}) \mathrm{Ba}\left(\mathrm{Mg}_{1 / 2} \mathrm{~W}_{1 / 2}\right) \mathrm{O}_{3}-\mathrm{xBa}\left(\mathrm{RE}_{2 / 3} \mathrm{~W}_{1 / 3}\right) \mathrm{O}_{3}(\mathrm{RE}=\mathrm{Sm}, \mathrm{Dy}, \mathrm{Y}$, Yb) Solid Solutions," J. Eur. Ceram. Soc., 35 [5] 1431-39 (2015).

12. Y.-J. Lin, S.-F. Wang, S.-H. Chen, Y.-L. Liao, and C.-L. Tsai, "Microwave Dielectric Properties of $\left(\mathrm{Ba}_{1-\mathrm{x}} \mathrm{Sr}_{\mathrm{x}}\right)\left(\mathrm{Mg}_{0.5} \mathrm{~W}_{0.5}\right) \mathrm{O}_{3}$ Ceramics," Ceram. Int., 41 [7] 8931-35 (2015).

13. J. J. Bian and J. Y. Wu, "Structure and Microwave Dielectric Properties of B-site Deficient Double Perovskite $\mathrm{Ba}\left[\left(\mathrm{Mg}_{(1-\mathrm{x}) / 2} \mathrm{Y}_{\mathrm{x} / 3} \square_{\mathrm{x} / 6}\right) \mathrm{W}_{1 / 2}\right] \mathrm{O}_{3}$, Ceram. Int., 42 [2] 3290-95 (2016).

14. S. Kim, C.-B. Hong, S.-H. Kwon, and S.-O. Yoon, "Microwave Dielectric Properties of $\mathrm{Ba}_{2}\left(\mathrm{Mg}_{1-2 \mathrm{x}} \mathrm{Y}_{2 \mathrm{x}} \mathrm{W}_{1-\mathrm{x}} \mathrm{Ti}_{\mathrm{x}}\right) \mathrm{O}_{6}$ Ceramics," J. Ceram. Process. Res., 18 [6] 421-24 (2017).

15. R. D. Shannon, "Revised Effective Ionic Radii and Systematic Studies of Interatomic Distances in Halides and Chalcogenides," Acta Cryst., A32 751-67 (1976).

16. S. H. Yoon, D.-W. Kim, S.-Y. Cho, and K. S. Hong, "Investigation of the Relations between Structure and Microwave Dielectric Properties of Divalent Metal Tungstate Compounds," J. Eur. Ceram. Soc., 26 [10-11] 2051-54 (2006).

17. I. M. Reaney, E. L. Colla, and N. Setter, "Dielectric and Structural Characteristics of Ba- and Sr- based Complex Perovskites as a Function of Tolerance Factor," Jpn. J. Appl. Phys., 33 [7A] 3984-90 (1994). 